\title{
ERRATA
}

\section{THE ORIGIN OF THE ROTATIONAL BARRIER IN DIMETHYL ETHER AND DIMETHYL SULFIDE. A THEORETICAL STUDY}

\author{
[Journal of Theoretical and Computational Chemistry, Vol. 6, No. 3 (2007) 421-434]
}

\author{
JÍMENEZ-FABIAN and A. F. JALBOUT \\ Instítuto de Químíca \\ Universídad Nacional Autonoma de Mexico \\ Mexico D.F.
}

\author{
The correct first author name should be: \\ I. JÍMENEZ-FABIAN
}

